\title{
Chlamydia trachomatis infection of cultured motile cells after uptake of chlamydiae from the substratum
}

\author{
S. CAMPBell, ${ }^{1 *}$ P. S. Yates ${ }^{2}$ and S. J. Richmond ${ }^{2}$ \\ ${ }^{1}$ Department of Obstetrics and Gynaecology, University Hospital of South Manchester, Nell Lane, \\ West Didsbury $M 208 L R, U K$ \\ ${ }^{2}$ Division of Virology, Department of Pathological Sciences, Stopford Building, University of Manchester, Oxford Rd, \\ Manchester M13 9PT, UK
}

(Received 20 January 1993; revised 17 April 1993; accepted 30 April 1993)

\begin{abstract}
The ability of motile cells to remove small inanimate particles from solid substrata is well documented. We show here that motile cells will pick up and internalize infectious particles of the obligate intracellular parasite Chlamydia trachomatis when they are adherent to the substratum over which the host cells move. Two cell types were used to assess chlamydial uptake; a feeder independent human squamous cell carcinoma variant (AC3A cells) and the McCoy cell line. Purified chlamydial elementary bodies were attached to glass or collagen-coated glass by centrifugation. Suspensions of cells were then allowed to sediment on to the substrata to which chlamydiae had attached. Both types of cell picked up chlamydiae and transported them over their surface during the course of attachment and spreading. Stereoscopic images obtained by confocal microscopy demonstrated that chlamydiae were found mainly on the surface of non-spread cells. After the cells had spread on the substratum they began to move around forming tracks where the chlamydiae had been removed. Some cell-surface-attached chlamydiae were endocytosed and a proportion of these proliferated during the $48 \mathrm{~h}$ after plating. However, chlamydiae attached to the substratum lost infectivity by a simple exponential decay process within a few hours of incubation in the extracellular environment. Therefore, increasing numbers of non-viable organisms were probably endocytosed as the time of extracellular incubation increased. This mode of infection may be relevant to in vivo situations where cell migration occurs after damage to mucosal surfaces.
\end{abstract}

\section{Introduction}

As epithelial cells migrate into wounds they internalize debris from the wound bed (Odland \& Ross, 1968). An in vitro equivalent of this activity is observed when small inanimate particles are removed from the substratum by cultured locomotory cells (Abercrombie et al., 1970; Harris \& Dunn, 1972; Albrecht-Buehler, 1976, 1977 a, b; Albrecht-Buehler \& Goldman, 1976; Albrecht-Buehler \& Lancaster, 1976; Dembo \& Harris, 1981). In previous work we found that keratinocytes at the periphery of expanding endometrial epithelial cell sheets became infected after they had migrated over collagen-coated glass on to which infectious particles of Chlamydia trachomatis had been centrifuged. We suggested that epithelial cells could pick up chlamydiae in the same way that other cell types handle small inanimate particles

\footnotetext{
*Author for correspondence. Tel. (061) 447 3812; fax (061) 445 1186.
}

attached to the substratum. This uptake process, which we called 'kinetoendocytosis', appeared to be much more efficient at initiating productive chlamydial infection than presentation of chlamydiae to the apical surface of keratinocytes within cell sheets (Campbell et al., 1988).

This work raised the possibility that in vivo, after trauma or menstruation, epithelial cells became infected by 'picking up' chlamydial particles as the cells migrated into wounded regions in the course of mucosal repair (Campbell et al., 1988). Such phenomena may be of clinical significance since there is evidence to suggest that in both conjunctiva (Jones, 1975; Hanna, 1971) and the genital tract (Hilton et al., 1974; Oriel \& Ridgway, 1982; Batteiger et al., 1989) mucosal damage reactivates preexisting quiescent chlamydial infection. Such exacerbation may also contribute to persistence of infection.

In the experiments which we now report we show that individual motile epithelial cells remove chlamydial particles bound to solid substrata, transport them over 
the cell surface and subsequently internalize them. A proportion of organisms endocytosed in this way undergo productive infection.

\section{Methods}

Cell culture. The AC3A cells were a gift of Dr Ken Parkinson (Beatson Institute for Cancer Research, Glasgow). These cells were selected as a feeder independent variant of a human squamous cell carcinoma line, and were used at a passage number of five or less. They were shown to be free of mycoplasma by staining with the fluorescent dye Hoechst 33258 . Preliminary observations demonstrated that these cells were highly motile when compared to McCoy cells and could be infected by centrifugation of chlamydiae onto their apical surface, which made them suitable for use in this study. The growth medium used was a 50:50 mix of Ham's F12:DMEM (Sigma) supplemented with $10 \%(\mathrm{v} / \mathrm{v})$ foetal calf serum, $2 \mathrm{~mm}$-glutamine, $10^{-7} \mathrm{M}$-hydrocortisone, $100 \mu \mathrm{g}$ streptomycin $\mathrm{ml}^{-1}$.

Substratum coating. Tendon collagen was prepared by acetic acid $(0.5 \mathrm{M})$ extraction of rat tail tendons (Elsdale \& Bard, 1972). Glassbottomed flasks or glass coverslips were coated by incubation with the acidic collagen solution for $1 \mathrm{~h}$ at $37^{\circ} \mathrm{C}$. Excess soluble collagen was then removed by a rapid wash with $0.5 \mathrm{M}$-acetic acid. The acid was then neutralized by washing five times with Dulbecco's phosphate-buffered saline, pH 7.2 (PBS) that contained phenol red. Other adhesion factors were used to coat glass coverslips by incubation for $1 \mathrm{~h}$ at $37^{\circ} \mathrm{C}$. These factors were poly-L-lysine $\left(10 \mu \mathrm{g} \mathrm{ml}^{-1}\right.$, Sigma), fibronectin $\left(10 \mu \mathrm{g} \mathrm{ml}^{-1}\right.$, BRL), and Matrigel (BRL) diluted 1:50 with cold growth medium. The coverslips were then washed with PBS immediately before use.

Growth, purification, and deposition of chlamydiae. A genital serotype $\mathrm{E}$ isolate of C. trachomatis (Sompolinsky \& Richmond, 1974) was grown in McCoy cells (Flow). Infected cell homogenates were prepared by shaking with glass beads. Purified chlamydiae were recovered from the infected cell homogenate by density gradient centrifugation (Howard et al., 1974) or by differential filtration with $0.6 \mu \mathrm{m}$ and $0.2 \mu \mathrm{m}$ pore diameter polycarbonate membrane filters (Campbell et al., 1991).

The removal of chlamydiae from the substratum by host cells was studied by coating coverslips at high density with filter-purified chlamydiae. Chlamydiae purified from one infected $25 \mathrm{~cm}^{2}$ flask of confluent McCoy cells were attached by centrifugation at $2400 \mathrm{~g}$ for $1 \mathrm{~h}$ to six glass or collagen-coated glass coverslips (at least $10^{6}$ chlamydial elementary bodies per $10 \mathrm{~mm}$ diam. coverslip), immediately before addition of the cells unless otherwise indicated. The total inoculum should not be compared with that reported in conventional experiments as chlamydiae lose viability in the extracellular environment. Consequently the eukaryotic cells did not actually encounter viable chlamydiae during most of the incubation period. In addition large parts of the coverslips were also never occupied by eukaryotic cells in most experiments. A large number of chlamydiae were used merely to achieve an even and high density coating of the coverslips and so maximize the probability that most cells would encounter viable chlamydiae during the early incubation period.

Chlamydiae were metabolically labelled with high-specific-activity $\left[{ }^{14} \mathrm{C}\right]$ threonine $\left(228 \mu \mathrm{Ci} \mathrm{mmol}^{-1}, 8 \cdot 44 \mathrm{MBq} \mathrm{nmol}^{-1}\right)$ in the presence of $4 \mu \mathrm{g}$ cycloheximide $\mathrm{ml}^{-1}$ (Allan \& Pearce, 1982; Campbell et al., 1991) in order to study chlamydial binding to glass or glass that had been coated with the attachment factors described above. The organisms were purified on renographin gradients and filtered through $0.6 \mu \mathrm{m}$ pore diam. polycarbonate membrane filters (Nucleopore) to exclude chlamydial reticulate bodies (Campbell et al., 1991). In one series of experiments a chlamydial suspension in $200 \mu 1$ PBS $\left(2 \times 10^{5}\right.$ c.p.m. $)$ was exposed directly to the glass scintillation vials, with or without coating, and then incubated in duplicate for $18 \mathrm{~h}$ at $37^{\circ} \mathrm{C}$. In other experiments chromic-acid-washed glass coverslips were placed in flat-bottomed plastic tubes and then exposed to the suspension. The amount of chlamydiae remaining in suspension after incubation or centrifugation was determined by scintillation counting a $50 \mu \mathrm{l}$ aliquot in $1 \mathrm{ml}$ of scintillation fluid (Ecoscint, Mensura). Coverslips were washed twice and transferred to glass vials for counting. In experiments where glass vials rather than coverslips were used binding was measured directly in the vial. The effect of centrifugation on binding was examined after centrifugation of the organisms at $2400 \mathrm{~g}$ for $1 \mathrm{~h}$ at $37^{\circ} \mathrm{C}$ and compared to binding without centrifugation in the same experiment. The stability of chlamydial binding to glass after centrifugation was determined by counting the amount of radioactivity on the substratum and that present in the overlying solution $(100 \mu \mathrm{l}$ aliquot) at hourly intervals over a period of $8 \mathrm{~h}$.

Analysis of eukaryotic cell spreading and motility. The AC3A cells were suspended with trypsin $(0.025 \%)$ and $10 \mathrm{~mm}$-EDTA, washed 3 times in $10 \mathrm{ml}$ PBS, resuspended in the appropriate medium and allowed to sediment onto glass-bottomed flasks (Campbell et al., 1989) or $10 \mathrm{~mm}$ diam. coverslips in flat-bottomed plastic tubes (Nunclon). The culture medium used was either that indicated above or a commercial low protein hybridoma medium (Gibco BRL) with or without serum. After various periods of attachment the cells were fixed in $2 \%(\mathrm{v} / \mathrm{v})$ formaldehyde in unsupplemented growth medium and examined with a $\times 40$ phase lens in order to characterize their spreading behaviour. Cell outlines were analysed manually by tracing around the periphery of 100 or 50 cells with a computer-based measuring system (Measure Mouse, AMS). Projected area and circularity $\left(4 \pi\right.$ area/perimeter $\left.{ }^{2}\right)$ were used as parameters of cell size and shape. (An object with a perfectly circular outline has a value of $t$, non-circular objects, such as a cell that has begun to extend protrusions, have a value of less than 1.) Statistical comparison was made with a two-sample $t$-test (Minitab).

Cell locomotion was followed by time-lapse video recording with an inverted phase microscope (Diavert, Lietz; or TMS, Nikon) fitted with $\times 10$ or $\times 4$ objectives. The cultures were continuously illuminated with low-intensity red light. Video images were obtained with an ER Newvicon camera (Panasonic) and recorded with Super-VHS timelapse recorder (AG-6720, Panasonic). Still video images were captured from the time-lapse video recordings with a digital time-base corrector and frame store (P147-15, CEL Electronics). All recordings ( $n=5$ for each treatment) were started $1 \mathrm{~h}$ after plating when the cells had attached and begun to spread. The position of each cell was then recorded at hourly intervals by capturing a still frame and then tracing around the cell periphery with the computer mouse using the system mentioned above. The co-ordinates of successive boundary centroids were used to calculate the displacement (squared) of each cell from its starting point (Gail \& Boone, 1970).

Fluorescence and confocal microscopy. Chlamydiae were visualized with a monoclonal antibody to chlamydial lipopolysaccharide produced in this laboratory and a FITC-conjugated rabbit anti-mouse antibody (Sigma). Fluorescent specimens were photographed with monochrome film (HP5, Ilford) rated at 1600 or 3200 ASA. Tracks formed by removal of fluorescent particles from the substratum were recorded with a $\times 25$ oil-immersion phase lens. Track size was measured directly from photographic negatives using the measuring system described above. The boundary of the tracks was traced manually and the track area and longest dimension (greatest linear distance separating two points on the perimeter), were used as measures of track size. An average of 60 randomly chosen tracks were measured for each culture condition used.

The uptake of chlamydiae by the epithelial cells was assessed by fixing the cultures with methanol at various times after plating. The 
chlamydiae were detected by indirect immunofuorescence and examined at high magnification ( $\times 100$ objective) using conventional epi-illumination and confocal microscopy (LSM, Zeiss). Confocal microscopy was used to map the distribution of the chlamydiae which became associated with the cells in three dimensions. The LSM was initially focused on the plane of the substratum and a digital image recorded $(512 \times 512$ pixels). The plane of focus was then automatically moved away from the substratum in successive $200 \mathrm{~nm}$ intervals so that the distribution of fluorescently-stained chlamydiae throughout the eukaryotic cell could be recorded. Stacks of these digital images were synthesized into composite images, using the manufacturer's software. Depth information in these composites was presented as left-right or red-green stereoscopic pairs or as colour overlays in which the distance of chlamydiae from the substratum was colour coded.

Loss of chlamydial viability when attached to the substratum. Chlamydial elementary bodies are known to lose viability in the extracellular environment. The kinetics of the chlamydial decay process were examined so that the period over which the host cells were likely to encounter viable chlamydiae could be established. The McCoy cell line was chosen for this work because these cells can survive in suspension at $4{ }^{\circ} \mathrm{C}$ for at least 2 weeks.

McCoy cells were cultured in the same medium used for AC3A cells, harvested with trypsin/EDTA and stored in suspension in growth medium overnight at $4{ }^{\circ} \mathrm{C}$. This was done in order to ensure that precisely the same number of cells were used in each part of the experiment, and that the cell suspension technique was uniform. Chlamydiae were centrifuged on to glass coverslips as described above. At the end of centrifugation and at a series of times thereafter 25000 McCoy cells, which had been pre-heated at $37^{\circ} \mathrm{C}$ for $1 \mathrm{~h}$, were added to each coverslip. These cells sedimented within $20 \mathrm{~min}$, attached and spread on the substratum, moved around, proliferated, and picked up chlamydial particles. Forty-eight hours after each McCoy cell addition the cultures were fixed with methanol and stained by indirect immunofluorescence to identify the cells which had become productively infected. The proportion of productively infected cells was recorded in 20 different fields at each time point. The decline in the proportion of infected cells with time was then mathematically modelled with a weighted non-linear least squares regression program, made available by Dr W. G. Bardsley, University of Manchester.

\section{Results}

\section{Effect of different substrata on $A C 3 A$ cell behaviour and on chlamydial binding}

AC3A cells cultured on plastic or collagen-coated glass in the presence of serum were highly active and moved extensively over the substratum (Fig. 1). A series of experiments were undertaken to define conditions which promoted cell spreading and locomotion on glassbottomed flasks and coverslips, so that cell behaviour could be manipulated in the presence of chlamydiae. Four glass coatings were tested for their ability to promote AC3A cell spreading when cultured in serumfree medium for $3 \mathrm{~h}$. Collagen coating was the most effective of those investigated (Table 1). Cells which spread on collagen had a significantly larger projected area $(P<0.001)$ than cells that spread on glass or the other attachment factors. Variations in cell spreading were reflected in changes in cell motility. Cell dis-

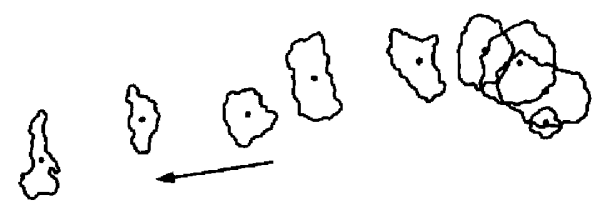

Fig. 1. The position of one AC3A cell moving on collagen-coated glass in the presence of serum was recorded from the time of attachment and at successive hourly intervals up to $9 \mathrm{~h}$. The outline of the cell and the position of the boundary centroid $(\cdot)$ are shown. Note how during migration the cell undergoes cycles of retraction and spreading; a phenomenon which may be relevant to chlamydial uptake. Bar, $10 \mu \mathrm{m}$.

\section{Table 1. Spreading of AC3A cells on glass or glass coated with a variety of attachment factors}

AC3A cells were suspended in serum-free medium and added to flat-bottomed tubes that contained glass coverslips. After $3 \mathrm{~h}$ the cells were fixed, mounted on microscope slides and the outline of 100 cells was traced for each treatment condition with cells selected from triplicate coverslips. The data are the means and $95 \%$ confidence intervals of each parameter. Circularity varies between 1 and 0 , with perfectly circular outlines having a value of 1 . Cells which spread on collagen were significantly more spread and less circular than those spreading on glass $(P<0.001)$.

\begin{tabular}{lcc}
\hline \hline & Area $\left(\mu \mathrm{m}^{2}\right)$ & Circularity \\
\hline Glass & $805(771-899)$ & $0.865(0.844-0.888)$ \\
Collagen & $2026(1804-2332)$ & $0.765(0.727-0.803)$ \\
Fibronectin & $1267(1117-1416)$ & $0.864(0.847-0.878)$ \\
Polylysine & $1028(940-1116)$ & $0.861(0.844-0.878)$ \\
Matrigel & $775(682-869)$ & $0.796(0.763-0.827)$ \\
\hline
\end{tabular}

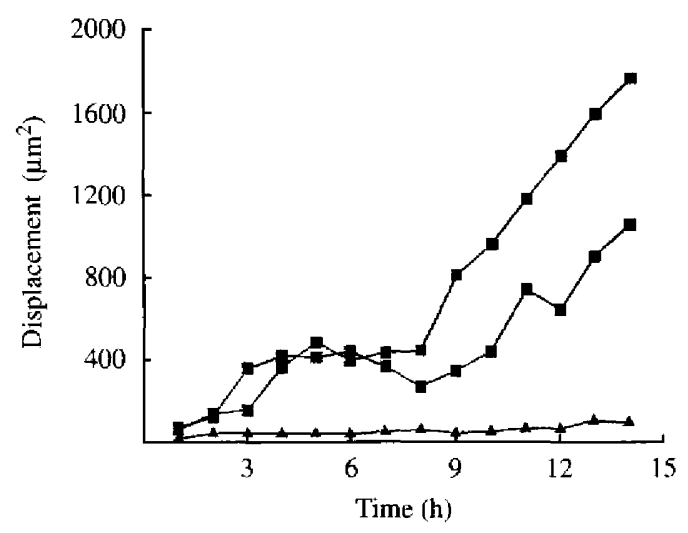

Fig. 2. AC3A cells cultured in serum-free medium on glass ( $\mathbf{A}$ ) showed only small displacements of the centroid with no significant translocation whereas those cultured on collagen in the presence of serum ( $\boldsymbol{\square}$ ) in two separate experiments became dispersed over a large area.

placement was much greater when the substratum was collagen-coated and serum was present in the medium (Fig. 2).

Radiolabelled purified chlamydiae did not show any preferential attachment to glass coverslips coated with acid-soluble rat-tail tendon solution (collagen), fibro- 

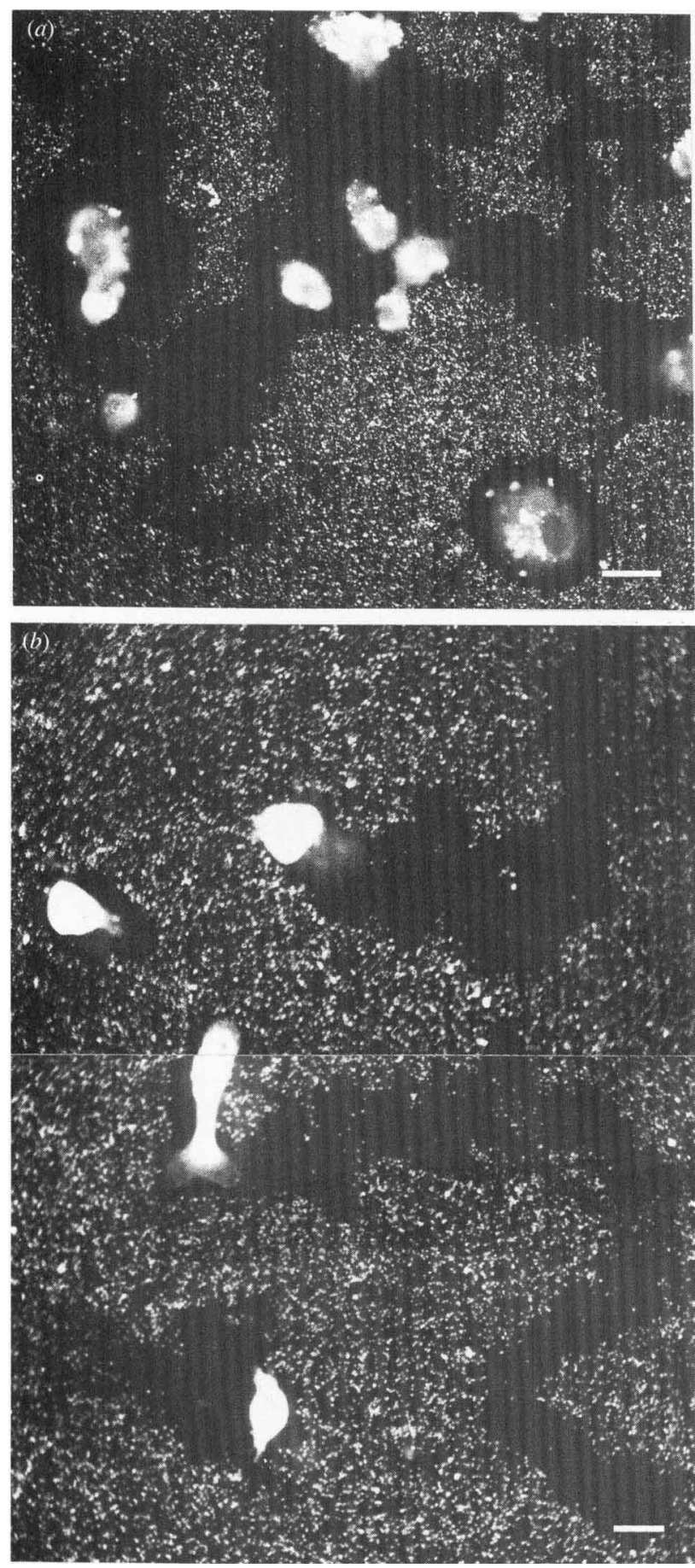

Fig. 3. AC3A cells in the presence of serum were allowed to sediment on to collagen-coated glass coverslips to which chlamydiae had been attached by centrifugation. After 24 or $48 \mathrm{~h}$ the cultures were fixed and the chlamydiae visualized by staining with a monoclonal antibody to chlamydial lipopolysaccharide and an anti-mouse FITC-conjugated immunoglobulin. (a) After $24 \mathrm{~h}$ at high plating density of AC3A cells, tracks made by removal of chlamydiae were present in various sizes and shapes. Bar, $40 \mu \mathrm{m}$. (b) Tracks formed by AC3A cells plated at lower density after $48 \mathrm{~h}$ in culture. Some of these tracks were long and extensive whereas others were restricted to a small domain around the point where the cells initially attached. Bar, $20 \mu \mathrm{m}$. nectin $\left(10 \mu \mathrm{g} \mathrm{ml}^{-1}\right)$, the basal laminal extract derived from EHS Sarcoma matrix (Matrigel), or polylysine $\left(10 \mu \mathrm{g} \mathrm{ml}^{-1}\right)$ compared to uncoated glass (data not shown). When chlamydial particles were centrifuged onto uncoated glass they remained stably attached over $8 \mathrm{~h}$ in the conditions used. Scintillation counting of coverslips ( $n$ 2) and an aliquot of medium showed no accumulation of radioactivity in the culture medium after $8 \mathrm{~h}$, or loss from the coverslips (3977 c.p.m. immediately after centrifugation, 4137 c.p.m. after 8 h). This result was supported by immunofluorescence microscopy which demonstrated a similar density of particles on the substratum immediately after centrifugation and $48 \mathrm{~h}$ later. Glass or collagen-coated glass was therefore used in all other experiments and chlamydiae were centrifuged on to these surfaces.

Removal of chlamydiae from the substrata by $A C 3 A$ cells

The behaviour of AC3A cells in the presence of substratum-attached chlamydiae was first observed by transferring an infected coverslip culture to a $25 \mathrm{~cm}^{2}$ plastic tissue-culture flask where it could be examined by video time-lapse microscopy. The presence of chlamydiae on the substratum produced no obvious qualitative change in cell morphology or motility. Although it was not possible to observe the removal of individual chlamydiae from the substratum with long-workingdistance phase microscopy, the migration of cells over a substratum covered with chlamydiae-infected cell homogenate left tracks of cleared areas where chlamydiae and cell debris had been removed. The formation of these tracks was most easily detected by fluorescence microscopy of fixed cells attached to coverslips (Fig. 3).

The process of chlamydial uptake from the substratum began within $2.5 \mathrm{~h}$ of cell attachment. At the start of the attachment and spreading process the cells were almost spherical. Most organisms that associated with host cells at this stage were found on the surface although a few chlamydiae were already internalized (Fig. $4 a-c$ ). Stereoscopic reconstruction of unspread cells with confocal microscopy demonstrated that the majority of chlamydiae remained on or near the surface (stereo pairs not shown). When the cells began to spread and develop a non-symmetrical morphology the distribution of organisms on the surface sometimes became nonuniform (Fig. $4 d$ ). This was assumed to be due to a redistribution of surface-exposed receptors with which the chlamydiae became associated. After a period of $24 \mathrm{~h}$ in culture, when long tracks had formed, the particles were found at the leading and trailing edges of the cells (Fig. $5 a$ ), within the cytoplasm or on the apical surface, sometimes grouped in little clusters (Fig. $5 b$ ). Some 

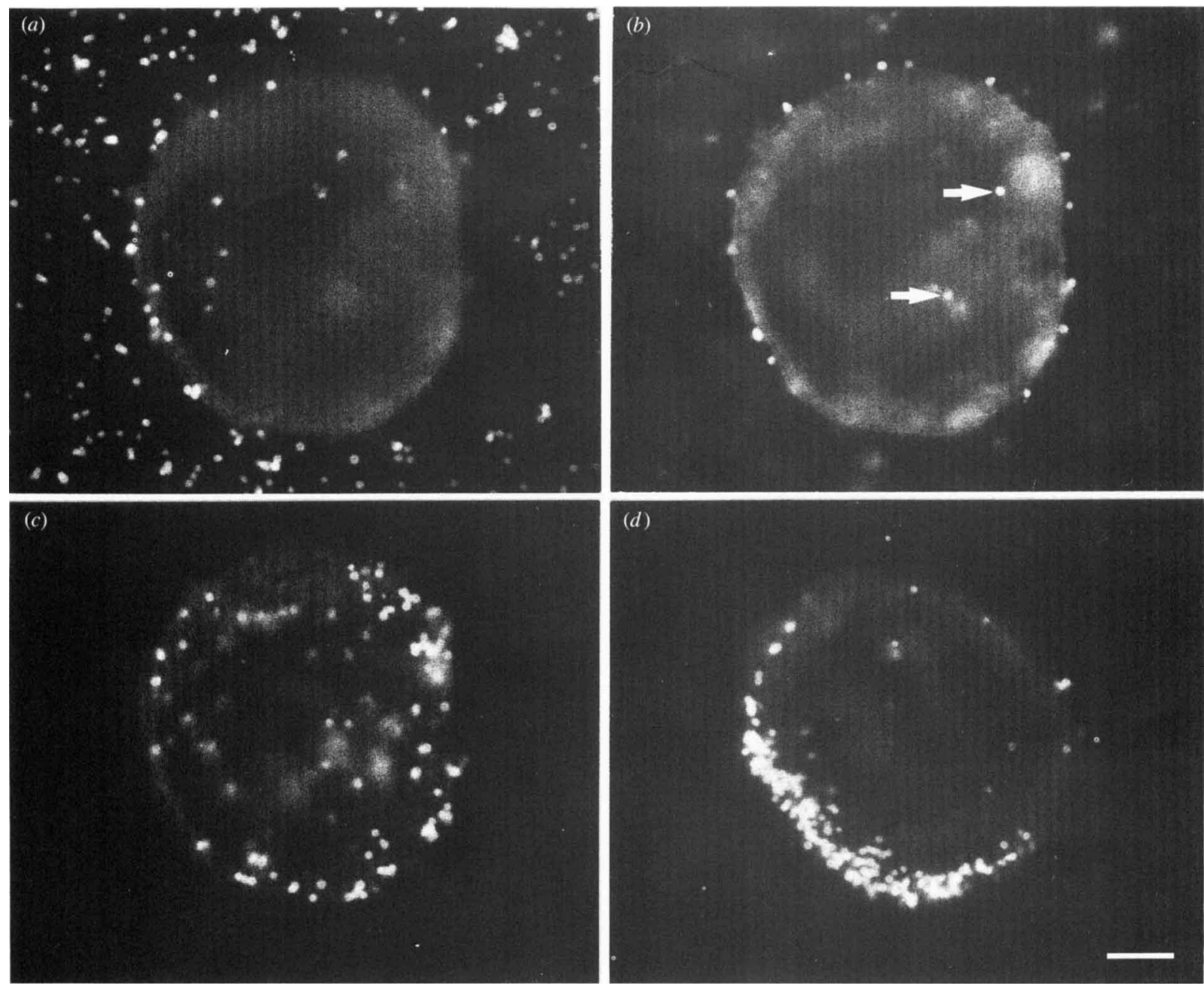

Fig. 4. AC3A cells were treated as in Fig. 3 and examined by fluorescence microscopy after $2.5 \mathrm{~h}$ culture. The unspread cell $(a-c)$ is shown in three consecutively higher focal planes. (a) Chlamydial particles on the substratum adjacent to the cell. Most particles have been removed from the area beneath the cell although a few particles can still be viewed in sharp focus in this region, which suggests they are still attached to the substratum. (b) Fourteen chlamydial particles are associated with the cell surface and two particles within the cytoplasm (arrows). (c) Particles are probably present both on the upper cell surface and within the cytoplasm. (d) A highly localized distribution of chlamydia is shown in another cell that had just begun to spread on to the substratum, despite an even distribution on the collagen-coated glass around the cell. Bar, $10 \mu \mathrm{m}$.
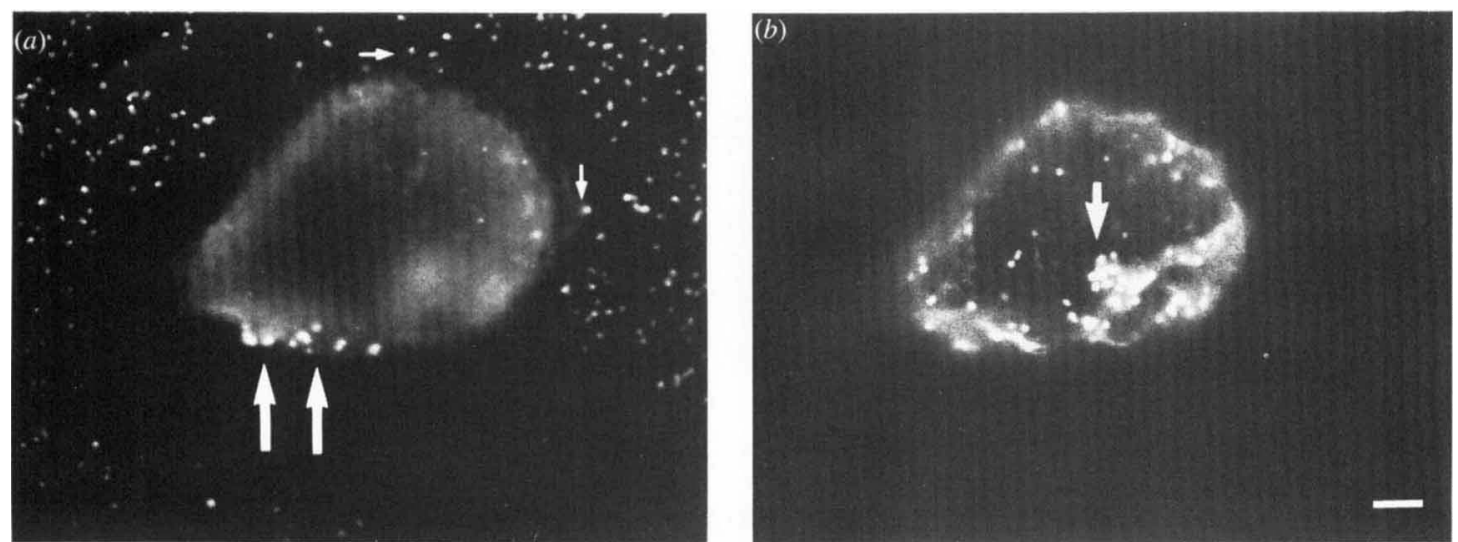

Fig. 5. An AC3A cell treated as in Fig. 3 and examined after $24 \mathrm{~h}$ in culture. The cell, which is shown in two focal planes, is at the end of a track. (a) On the plane of the substratum the cell track formed by the removal of chlamydiae can be seen. Two chlamydial particles are visible at the leading edge of the cell (small arrows). A group of particles is present at the trailing edge of the cell (large arrows) in a plane slightly above the substratum. (b) A small group of particles is present on or near the upper surface of the cell (arrow). Bar, $5 \mu \mathrm{m}$ 


\section{Table 2. Track formation by AC3A cells in different culture conditions after $48 \mathrm{~h}$}

The outline of tracks formed by the removal of chlamydiae was traced manually over images of immunofluorescence micrographs. The presence of either collagen or serum was enough to increase the area of particles cleared, although serum also induced cell proliferation. The data shown are obtained from at least 3 coverslips and are the means of each parameter. Tracks formed in the presence of both serum and collagen were too extensive to be quantiffed reliably.

\begin{tabular}{lccccc}
\hline \hline $\begin{array}{c}\text { Nolture } \\
\text { conditions }\end{array}$ & $\begin{array}{c}\text { No. of } \\
\text { tracks }\end{array}$ & $\begin{array}{c}\text { No. of } \\
\text { cells } \\
\text { per track }\end{array}$ & $\begin{array}{c}\text { Track } \\
\text { area } \\
\left(\mu \mathrm{m}^{2}\right)\end{array}$ & $\begin{array}{c}\text { Area } \\
\text { per cell } \\
\left(\mu \mathrm{m}^{2}\right)\end{array}$ & $\begin{array}{c}\text { Longest } \\
\text { track } \\
\text { dimension } \\
(\mu \mathrm{m})\end{array}$ \\
\hline $\begin{array}{c}\text { Low protein } \\
\text { glass } \\
\begin{array}{c}\text { Low protein } \\
\text { collagen } \\
\text { Low protein } \\
\text { serum/glass }\end{array}\end{array}$ & 65 & 1.11 & 1836 & 1869 & 63 \\
\hline \hline
\end{tabular}

particles were observed beneath rounded and well spread cells in the focal plane of the substratum. Confocal microscopy confirmed that although most chlamydiae were dislodged by the advancing lamellipodia some were not taken onto the apical surface, but instead remained trapped beneath the cell (colour composite images not shown).

Modifications of the culture conditions which gave rise to altered cell behaviour (Fig. 2) produced a change in chlamydial uptake from the substratum. When cells were cultured in conditions unfavourable for cell spreading and movement only small areas of substratum were cleared of chlamydiae (Table 2). When conditions were made more favourable by either coating the substratum with collagen or adding serum to the medium, track area and length increased $(P<0.001$ for each situation). This can be partially explained by the fact that the area of substratum cleared per cell was greater when serum was present $(P<0 \cdot 0001)$. However the AC3A cells also proliferated in the presence of serum so that by $24 \mathrm{~h}$ there was more than one cell per track (Fig. $3 a$ ). If the tracks were formed in growth medium with serum in the presence of collagen then they became very extensive, overlapped and were consequently difficult to quantify. Thus the conditions which promoted cell spreading, locomotion and proliferation led to the largest removal of chlamydiae from the substratum. In conditions where the cells were more spread, moved further over the substratum and proliferated, more chlamydiae were removed.

\section{Fate of endocytosed chlamydiae}

Some of the chlamydiae which were removed from the substratum were endocytosed into the cell in a viable state, for some of the host cells developed inclusions (Fig. 6). Chlamydiae are known, however, to lose infectivity in the extracellular environment. It is therefore difficult to compare the efficiency of this route of infection with the classical method of centrifugal inoculation of chlamydiae on to the cell surface of preformed monolayers. The proportion of organisms that are capable of undergoing productive infection will depend on the viability of the internalized chlamydiae, which will decline with time. The kinetics of extracellular decay were measured by adding McCoy cells after the incubation of chlamydiae for various times on the substratum. Chlamydiae were centrifuged on to collagen-coated glass and McCoy cells were allowed to sediment at various times thereafter and the preparations examined $48 \mathrm{~h}$ after the addition of McCoy cells. The proportion of cells which became productively infected declined exponentially with time (Fig. 7). The host cells therefore encountered an
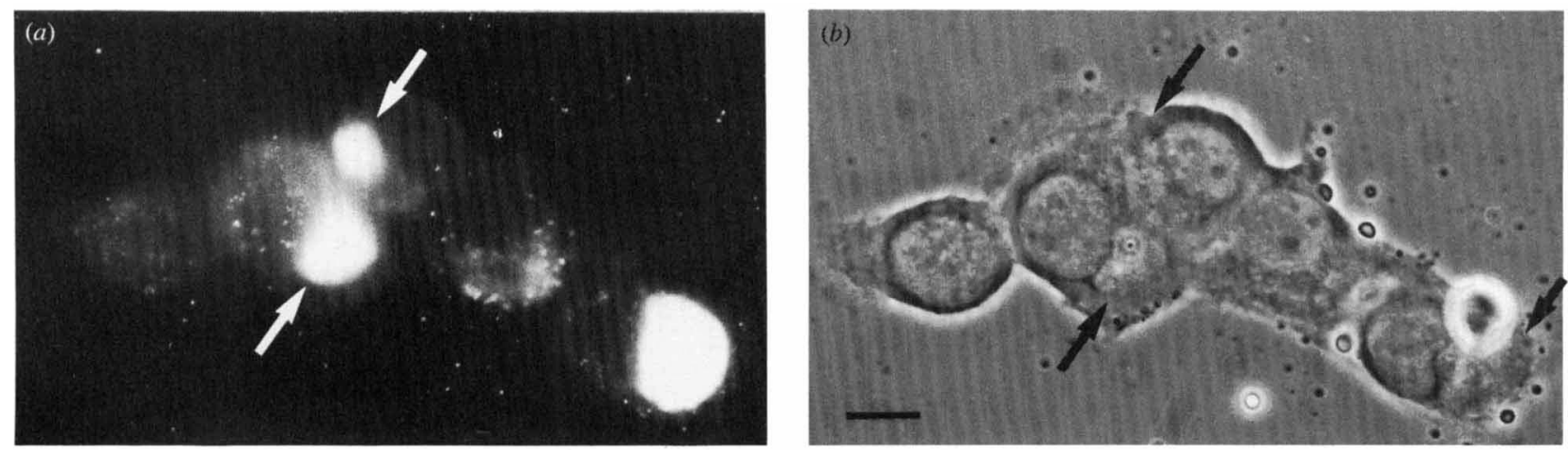

Fig. 6. AC 3A cells were treated as in Fig. 3 and examined after $48 \mathrm{~h}$ in culture. Three AC3A cells within a small group have developed inclusions (arrows) which are characteristic of productive infection. (a) A fluorescence micrograph shows three inclusions in which internalized chlamydiae have proliferated. Isolated, probably non-viable chlamydial particles can also be seen within the cytoplasm. (b) A phase micrograph of the same field indicates the intracytoplasmic location of the inclusions. Bar, $10 \mu \mathrm{m}$. 


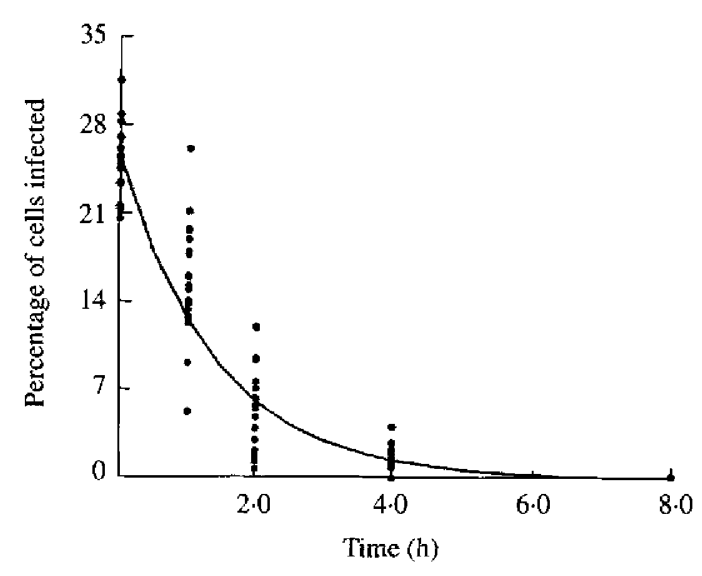

Fig. 7. Chlamydial viability decays with time before internalization into the host cell. McCoy cells were added at various times after the chlamydiae were centrifuged onto the substratum and the decay in the proportion of cells which subsequently developed an inclusion is recorded. No inclusions were seen after $\geqslant 8 \mathrm{~h}$. Each data point represents one microscope field which contained an average of 160 cells. The decline in viability can be described by a first-order exponential decay process (solid line). A more complex decay curve (i.e. a second order model) was not justified at the $95 \%$ confidence interval by this data set.

exponentially decaying population of extracellular chlamydial particles as they migrated over the substratum.

\section{Discussion}

The conventional way to infect cultured cells with $C$. trachomatis is to present the organisms to the surface of cell monolayers by centrifugation. This highly artificial procedure, which is used to force chlamydiae onto the monolayer surface because of their surprisingly low affinity for the target cells (Vretou et al., 1989; Ward \& Clarke, 1990), can obviously bear little relevance to infection of mucosal surfaces in vivo. We have described a different method of achieving in vitro infection, in which motile cultured cells pick up and endocytose chlamydiae attached to the substratum. This method may have relevance to in vivo infection of traumatized mucosal membranes by ocular and oculo-genital strains of $C$. trachomatis.

The uptake of chlamydial particles and their subsequent movement over the eukaryotic cell surface that we present here corresponds very closely to the way inanimate gold particles were picked up from the substratum and internalized by $3 \mathrm{~T} 3$ cells and a bovine aortic endothelial cell line (Albrecht-Buehler, $1977 a, b$; McAuslan \& Reilly, 1980). The gold particles used were $0 \cdot 2-0.4 \mu \mathrm{m}$ in diameter and thus very similar in size distribution to purified infectious particles of chlamydiae, which have a mean diameter of approximately $0.3 \mu \mathrm{m}$
(Campbell et al., 1991). The removal of gold particles from the substratum by lamellipodial or filipodial advancement and retraction cycles, which led to the formation of particle-depleted tracks (Albrecht-Buehler \& Goldman, 1976; Albrecht-Buehler \& Lancaster, 1976), is similar to the uptake of chlamydiae we demonstrate here. Such uptake, therefore, is not a microbe-specific process that requires both specific host receptors and parasite-specific ligands. This was confirmed during our work with chlamydia-infected cell homogenates, since cell debris as well as chlamydiae was cleared from the substratum.

Studies in which chlamydiae are presented to the surface of cell monolayers (with or without centrifugation) suggest that more than one endocytic mechanism may operate when chlamydiae enter host cells. Evidence exists for both involvement of receptormediated endocytosis via clathrin-coated pits (i.e. microfilament-independent pinocytosis) (Hodinka et al., 1988; Wyrick et al., 1989) and for microfilamentdependent phagocytosis (Ward \& Murray, 1984; Ward \& Clarke, 1990; Reynolds \& Pearce, 1991) and it appears that the mode of entry exploited by the parasite is influenced by the way the organisms are presented to the monolayers (Prain \& Pearce, 1989; Reynolds \& Pearce, 1991). We do not have any data on the entry mechanisms used after uptake of chlamydiae from the substratum, but more than one process may well be utilized.

Chlamydiae attached to the substratum lost infectivity rapidly by an exponential decay process, which may also operate after uptake whilst chlamydiae are associated with the host cell surface. Few organisms would still have been viable after attachment to the substratum for $8 \mathrm{~h}$, even though large numbers of viable chlamydiae were attached initially. Loss of viability is likely to be accompanied by a change in the intracellular fate of internalized organisms, with non-viable organisms being routed to lysosomes (Prain \& Pearce, 1989). The large numbers of single chlamydial organisms that could still be seen within the host cell after $48 \mathrm{~h}$ of cell culture confirms that many internalized chlamydiae did not undergo productive infection. It was impossible to quantify chlamydial routing to lysosomes (Prain \& Pearce, 1989) under the conditions of our experiments since cells were sparsely plated and the rapid, synchronous and abundant endocytosis needed for quantitative ultrastructural work did not occur.

Repair of damaged epithelial surfaces in vivo involves a rapid migration of motile epithelial cells into the wound bed to restore the integrity of the surface. The ability of motile cultured cells to pick up and internalize inanimate particles in vitro is probably reflected in vivo by internalization of debris from the wound bed in human skin during the healing process (Odland \& Ross, 1968). 
We have demonstrated that chlamydial particles can be internalized by a similar in vitro process that can lead to productive infection. Thus repair of mucosal surfaces of the eye and genital tract that have been physically, microbiologically or physiologically damaged may be accompanied by uptake of extracellular chlamydiae in the wound bed. Such organisms could be present as a result of either recent exogenous or pre-existing endogenous infection. For instance, at the time of menstruation, when physiological damage to the endometrium occurs, pre-existing infected epithelial cells may lyse, releasing infectious chlamydiae. If these organisms are exposed to the regenerating endometrial surfaces then the uptake, entry and infection processes we have described here may be relevant. Chlamydial infection by such a mechanism may in fact be more efficient than infection of intact epithelia. This would explain the microbiological and clinical exacerbations of chlamydial disease that are associated with mucosal trauma (Jones, 1975; Hanna, 1971; Hilton et al., 1974; Oriel \& Ridgway, 1982; Batteiger et al., 1989). The experiments reported here thus raise the possibility of a new biological significance for particle transport and endocytosis by non-phagocytic cells during repair of damaged mucosal surfaces.

This work was supported by an MRC project grant. The authors are grateful to Dr Bill Bardsley for providing curve fitting software, to Dr Terry Allen of the CRC Department of Structural Cell Biology, Paterson Laboratories for making the confocal microscope available, and to Dr John Pearce for helpful suggestions.

\section{References}

Abercrombie, M., Heasysman, J. E. M. \& Pegrum, S. M. (1970). The locomotion of fibroblasts in culture. III Movements of particles on the dorsal surface of the leading lamella. Experimental Cell Research 62, 389-398.

Albrecht-Buehler, G. (1976). Filopodia of spreading 3T3 cells. Do they have a substrate-exploring function? Journal of Cell Biology 69 , 275-286.

AlBrecht-BueHLER, G. (1977 a). The phagokinetic tracks of 3 T3 cells. Cell 11, 395 404.

Albrecht-Buehler, G. (1977b). Daughter 3T3 cells. Are they mirror images of each other? Journal of Cell Biology 72, 593-603.

Albrecht-Buehler, G. \& Goldman, R. D. (1976). Microspikemediated particle transport towards the cell body during early spreading of 3T3 cells. Experimental Cell Research 97, 329-339.

Albrecht-Buehler, G. \& Lancaster, R. M. (1976). A quantitative description of the extension and retraction of surface protrusions in spreading 3T3 mouse fibroblasts. Journal of Cell Biology 71, 370-382.

Allan, I. \& Ptarce, J. H. (1982). Radiolabelling of Chlamydia psittaci (strain guinea pig inclusion conjunctivitis) to high specific activity using ${ }^{14} \mathrm{C}$-labelled amino acids. FEMS Microbiology Letters 13 , $69-73$.

Batteiger, B. E., Fraiz, J., Newhall., W. J., Katz, B. P. \& Jones, R. B. (1989). Association of recurrent chlamydial infection with gonorrhoea. Journal of Infectious Diseases 159, 661-669.

Campbell, S., Richmond, S. J., Haynes, P., Gump, D., Yates, P. \& AlLEN, T. D. (1988). An in vitro model of Chlamydia trachomatis infection in the regenerative phase of the menstrual cycle. Journal of General Microbiology 134, 2077-2087.

Campbell, S., Richmond, S. J. \& Yates, P. (1989). The development of Chlamydia trachomatis inclusions within the host cell during interphase and mitosis. Journal of General Microbiology 135, $1153-1165$

Campbell, S., Yates, P. S., Waters, F. \& Richmond, S. J. (1991). Purification of Chlamydia trachomatis by a simple and rapid filtration method. Journal of General Microbiology 137, 1565-1569.

DemBo, M. \& HaRris, A. K. (1981). Motion of particles adhering to the leading lamella of crawling cells. Journal of Cell Biology 91, 528-536.

ElsDale, T. \& BARD, J. B. L. (1972). Collagen substrate for the study of cell behaviour. Journal of Cell Biology 54, 626-637.

GAIL, M. H. \& BoONE, C. W. (1970). The locomotion of mouse fibroblasts in tissue culture. Biophysics Journal 10, 980-993.

HANNA, L. (1971). Immunofluorescence in chronic TRIC infections of American Indians and Tunisians: influence of trauma and results of tests. In Trachoma and Related Disorders, pp. 461-468. Edited by R. L. Nichols. Amsterdam: Excerpta Medica.

HARRIS, A. K. \& DUNN, G. (1972). Centripetal transport of particles attached on both surfaces of moving fibroblasts. Experimental Cell Research 73, 519-523.

Hilton, A. L., Richmond, S. J., Milne, J. D., Hindley, F. \& Clarke, S. K. R. (1974). Chlamydia A in the female genital tract. British Journal of Venereal Diseases 50, 1-10.

Hotnika, R. L., Davis, C. H., ChoOng, J. \& Wyrick, P. B. (1988). Ultrastructural study of endocytosis of Chlamydia trachomatis by McCoy cells. Infection and Immunity 56, 1456-1463.

Howard, L., Orenstein, N. S. \& King, N. W. (1974). Purification on renografin gradients of Chlamydia trachomatis grown in the yolk sac of eggs. Applied Microbiology 27, 102-106.

JONES, B. R. (1975). The prevention of blindness from trachoma. Transactions of the Ophthalmology Society of the United Kingdom 95 , $16-33$.

MCAuslan, B. R. \& Reitly, W. (1980). Endothelial cell phagokinesis in response to specific metal ions. Experimental Cell Research 130 , $147-157$.

ODLAND, G. \& Ross, R. (1968). Human wound repair. I. Epidermal regeneration. Journal of Cell Biology 39, 135-151.

ORIEL, J. D. \& RIDGWAY, G. L. (1982). Epidemiology of chlamydial infection of the human genital tract: evidence for the existence of latent infections. European Journal of Clinical Microbiology 1, 69-75.

PraIN, C. J. \& Pearce, J. H. (1989). Ultrastructural studies on the intracellular fate of Chlamydia psittaci (strain guinea pig inclusion conjunctivitis) and Chlamydia trachomatis (strain lymphograntuloma venereum 434): modulation of intracellular events and relationship with endocytic mechanism. Journal of General Microbiology 135, 2107-2123.

ReYnolds, D. J. \& PeARCE, J. H. (1991). Endocytic mechanisms utilized by chlamydiae and their influence on induction of productive infection. Infection and Immunity 59, 3033-3039.

SOMPOLINSKY, D. \& Richmond, S. (1974). Growth of Chlamydia trachomatis in McCoy cells treated with cytochalasin B. Applied Microbiology 28, 912-914.

VRetou, E., Goswami, P. C. \& Bose, S. K. (1989). Adherence of multiple serovars of Chlamydia trachomatis to a common receptor on HeLa and McCoy cells is mediated by thermolabile protein(s). Journal of General Microbiology 135, 3229-3237.

WARD, M. E. \& ClaRkE, I. N. (1990). New perspectives in chlamydial biology and development. In Chlamydial Infections, pp. 3-14. Edited by W. R. Bowie, H. D. Caldwell, R. P. Jones, P.-A. Mardh, G. L. Ridgway, J. Schachter, W. E. Stamm \& M. E. Ward. Cambridge: Cambridge University Press.

Ward, M. E. \& MurRay, A. (1984). Control mechanisms governing the infectivity of Chlamydia trachomatis for HeLa cells : mechanisms of endocytosis. Journal of General Microbiology 130, 1765-1780.

Wyrick, P. B., Choong, J., Davis, C. H., KNiGht, S. T., Royal, M. O., Maslow, A. S. \& Bagnell, C. R. (1989). Entry of genital Chlamydia trachomatis into polarised human epithelial cells. Infection and Immunity 57, 2378-2389. 